\title{
MANIFESTASI KUALITAS KOMPETENSI PROFESIONALISME GURU DALAM MEMBANGUN PARADIGMA INSAN GENERASI EMAS
}

\author{
Yanti Gultom \\ Surel: yantigulatomat@yahoo.co.id
}

\begin{abstract}
ABSTRAK
Membangun generasi yang genius dan unggul adalah tujuan demi kemajuan bangsa. Akan tetapi, membangun generasi yang genius, unggul, dan berkarakter butuh keprofesionalisme seorang guru dalam proses pembelajaran. Profesionalisme guru merupakan kondisi, arah, nilai, tujuan dan kualitas suatu keahlian dan kewenangan dalam bidang pendidikan dan pengajaran yang berkaitan dengan pekerjaan seseorang yang menjadi mata pencaharian. Kualitas keahlian itu tercermin dalam kepemilikan kompetensi yang bersifat khusus, tingkat pendidikan minimal, dan sertifikasi keahlian. Profesionalisme mengacu pada hakekat mengajar yang merupakan usaha guru dalam menciptakan dan mendesain proses belajar siswa, guru lebih menghargai proses daripada hasil, sehingga tercipta sebuah pembelajaran yang aktif, inovatif, dan kreatif. Hal ini dapat dilakukan oleh seorang guru yang professional. Berdasarkan empat kriteria guru profesional, yaitu: ahli, memiliki tanggungjawab, berjiwa dinamis dan memiliki rasa kesejawatan. Empat kompetensi yang harus dimiliki oleh guru professional, yaitu kompetensi pedagogik, kompetensi kepribadian, professional dan sosial, maka diharapkan guru profesional akan mampu mencetak anak bangsa yang berkualitas guna membangun paradigma insan generasi emas Indonesia yang diharapkan.
\end{abstract}

Kata kunci: Profesionalisme, Kualitas Kompetensi, Generasi Emas

\section{PENDAHULUAN}

Pendidikan dapat dipahami dari dua sisi yang meliputinya, yaitu pendidikan sebagai sebuah produksi (education as product), dan pendidikan sebagai sebuah proses (education as process). Dua

sisi ini selalu berpengaruh dalam memahami dan melakukan kegiatan pendidikan dalam kehidupan nyata manusia. Pendidikan sebagai sebuah produksi muncul dari keinginan manusia itu sendiri untuk menghasilkan sesuatu, baik yang konkrit maupun yang abstrak sehingga muncul dalam dunia pendidikan untuk melakukan penilaian (evaluasi) sebagai hasil dari sebuah kegiatan pendidikan.

Dalam dunia pendidikan, peran dan fungsi guru merupakan salah satu faktor yang sangat signifikan. Guru merupakan bagian terpenting dalam proses belajar mengajar, baik di jalur pendidikan formal maupun informal. Oleh sebab itu, dalam setiap upaya peningkatan kualitas pendidikan di tanah air, tidak dapat dilepaskan dari berbagai hal yang berkaitan dengan eksistensi guru itu sendiri.

Filsofis sosial budaya dalam pendidikan di Indonesia, telah menempatkan fungsi dan peran guru sedemikian rupa sehingga para guru di Indonesia tidak

Pascasarjana Universitas Negeri Medan 
jarang telah di posisikan mempunyai peran ganda bahkan multi fungsi. Mereka dituntut tidak hanya sebagai pendidik yang harus mampu mentransformasikan knowledge, values, dan skill, tetapi sekaligus sebagai penjaga moral bagi anak didik. Bahkan tidak jarang, para guru dianggap sebagai orang kedua, setelah orang tua anak didik dalam proses pendidikan secara global.

Dalam era reformasi pendidikan, dimana salah satunya isu utamanya adalah peningkatan profesionalisme guru, hal itu merupakan sebuah keniscayaan yang tidak dapat ditawar-tawar lagi dalam mencapai pendidikan yang lebih berkualitas. Selain itu, pendidikan sebagai sebuah proses selalu berdampak pada sebuah upaya untuk senantiasa memperbaiki agar hasil tersebut menjadi baik. Untuk memperbaiki hasil pendidikan kita, tentu kita perlu tahu tentang kondisi pendidikan kita.

Kita sadari bahwa profesionalisme guru merupakan sebuah kebutuhan yang tidak dapat ditunda-tunda lagi, seiring dengan semakin meningkatnya persaingan yang semakin ketat dalam era globalisasi seperti sekarang ini. Diperlukan orang-orang yang memang benar benar-benar ahli di bidangnya, sesuai dengan kapasitas yang dimilikinya agar setiap orang dapat berperan secara maksimal, termasuk guru sebagai sebuah profesi yang menuntut kecakapan dan keahlian tersendiri. Profesionalisme tidak hanya karena faktor tuntutan dari perkembangan zaman. Tetapi pada dasarnya juga merupakan suatu keharusan bagi setiap individu dalam kerangka perbaikan kualitas hidup manusia. Profesionalisme menuntut keseriusan dan kompetensi yang memadai, sehingga seseorang dianggap layak untuk melaksanakan sebuah tugas.

Salah satu upaya untuk meningkatkan profesionalisme guru adalah melalui sertifikasi sebagai sebuah proses ilmiah yang memerlukan pertanggung jawaban moral dan akademis. Dalam isu sertifikasi tercermin adanya suatu uji kelayakan dan kepatutan yang harus dijalani seseorang, terhadap kriteria-kriteria yang secara ideal telah ditetapkan. Sertifikasi bagi para Guru dan Dosen merupakan amanah dari UU Sistem Pendidikan Nasional kita (pasal 42) yang mewajibkan setiap tenaga pendidik harus memiliki kualifikasi minimum dan sertifikasi sesuai dengan jenjang kewenangan mengajar yang dimilikinya. Singkatnya adalah, sertifikasi dibutuhkan untuk mempertegas standar kompetensi yang harus dimiliki para guru dan dosen sesuai dengan bidang keilmuannya masing-masing.

Menurut faktor lain yang harus dilakukan dalam mencapai profesionalism guru adalah, perlunya perubahan paradigma dalam proses belajar mengajar. Anak didik tidak lagi ditempatkan sekedar sebagai obyek pembelajaran tetapi harus berperan dan diperankan sebagai subyek. Sang guru tidak lagi sebagai instruktur yang harus memposisikan dirinya lebih tinggi dari anak didik, tetapi lebih berperan sebagai fasilitator atau konsultator yang bersifat saling melengkapi.

Dimana pendidikan merupakan sebuah investasi yang memiliki peranan stategis dalam mengembangkan sumber daya manusia yang berkualitas. Dalam konteks ini, guru dituntut untuk mampu melaksanakan proses pembelajaran yang 
efektif, kreatif dan inovatif secara dinamis dalam suasana yang demokratis serta pengembangan profesionalisme guru diarahkan pada peningkatan kualitas. Dengan demikian proses belajar mengajar akan dilihat sebagai proses pembebasan dan pemberdayaan, sehingga tidak terpaku pada aspek-aspek yang bersifat formal, ideal maupun verbal. Hal tersebut sangat penting untuk merekonstruksi dan mereformulasi desain pendidikan melalui profesionalisme guru yang dapat mendukung terciptanya generasi emas bangsa Indonesia. Dimana dukungan dan kualitas pendidikan yang bermutu dan berkarakter akan menjadi kunci membangkitkan paradigma insan generasi emas bangsa.

Berdasarkan latar belakang di atas, dapat dirumuskan beberapa rumusan masalah diantaranya sebagai berikut:1). apa yang dimaksud dengan profesionalisme guru?. 2). apa saja faktor yang mempengaruhi guru professional?. 3). Bagaimanakah upaya yang dilakukan untuk meningkatkan kualitas kompetensi dan profesionalisme guru?.

Tujuan penyusunan makalah ini antara lain sebagai berikut: 1). untuk mengetahui maksud dari profesionalisme guru, 2). untuk mengetahui faktor yang mempengaruhi guru professional, 3). untuk mengetahui upaya yang harus dilakukan untuk meningkatkan kualitas kompetensi dan profesionalisme guru.

\section{PEMBAHASAN}

\section{Kompetensi Guru}

Menurut Lefrancois dalam Asmani (2009) kompetensi merupakan kapasitas untuk melakukan sesuatu yang dihasilkan dari proses belajar. Selama proses belajar, stimulus akan bergabung dengan isi memori dan menyebabkan terjadinya perubahan kapasitas untuk melakukan sesuatu. Apabila individu sukses mempelajari cara melakukan sesuatu pekerjaan yang kompleks dari sebelumnya maka pada diri individu tersebut pasti sudah terjadi perubahan kompetensi.

Dengan demikian, bisa diartikan kompetensi proses yang berlangsung lama yang menyebabkan individu mampu melakukan kinerja tertentu. Kompetensi diartikan Cowell dalam Asmani (2009) sebagai suatu keterampilan atau kemahiran yang bersifat aktif. Berdasarkan uraian di atas, maka dapat disimpulkan bahwa kompotensi merupakan suatu kesatuan yang utuh yang menggambarkan potensi, pengetahuan, keterampilan, dan sikap yang dinilai yang terkait dengan profesi tertentu berkenaan dengan bagian yang dapat diaktualisasikan dan diwujudkan dalam bentuk tindakan atau kinerja untuk menjalankan profesi tertentu.

Menurut Undang-undang No. 14 tahun 2005 tentang Guru dan Dosen Pasal 1 ayat (10), kompetensi adalah seperangkat pengetahuan, keterampilan, dan perilaku yang harus dimiliki, dihayati dan dikuasai oleh guru atau dosen dalam melaksanakan tugas keprofesionalan. Berdasarkan Peraturan Menteri Pendidikan Nasional Republik Indonesia No. 16 tahun 2007 tentang Standar Kualifikasi Akademik dan Kompetensi Guru. Dijelaskan bahwa Standar Kompetensi Guru 
dikembangkan secara utuh dari 4 kompetensi utama, yaitu (1) kompetensi pedagogik, (2) kompetensi profesional, (3) kompetensi kepribadian, (4) kompetensi sosial. Keempat bidang kompetensi di atas tidak berdiri sendirisendiri, melainkan saling berhubungan dan saling mempengaruhi satu sama lain dan mempunyai hubungan hierarkis, artinya saling mendasari satu sama lainnya, kompetensi yang satu mendasari kompetensi yang lainnya.

\section{Profesionalisme Guru}

Istilah profesional pada umumnya adalah orang yang mendapat upah atau gaji dari apa yang dikerjakan, baik dikerjakan secara sempurna maupun tidak (Martinis Yamin, 2007). Dalam konteks ini bahwa yang dimaksud dengan profesional adalah guru. Pekerjaan profesional ditunjang oleh suatu ilmu tertentu secara mendalam yang hanya mungkin diperoleh dari lembaga-lembaga pendidikan yang sesuai sehingga kinerjanya didasarkan kepada keilmuan yang dimilikinya yang dapat dipertanggungjawabkan secara ilmiah (Wina Sanjaya, 2008).

Menurut Asmani (2009) guru profesional adalah guru yang mengajar pada mata pelajaran yang menjadi keahliannya, mempunyai semangat tinggi dalam mengembangkannya dan menjadi pioneer perubahan di tengah masyarakat.. Seseorang mempunyai bidang keahlian kalau ia mempunyai kompetensi yang memadai dan mendalam.

Menurut Sofyandi (2008) salah satu syarat guru sebagai pendidik profesional adalah memiliki kualifikasi akademik dan menguasai kompetensi sebagai agen pembelajaran. Hal tersebut erat kaitannya dengan sertifikasi guru sebagai salah satu upaya peningkatan mutu guru dan dibarengi dengan peningkatan kesejahteraan guru sehingga diharapkan dapat meningkatkan mutu pembelajaran dan mutu pendidikan di Indonesia secara menyeluruh dan berkelanjutan.

Dari pengertian di atas seorang guru yang profesional harus memenuhi empat kompetensi guru sebagaimana yang diamanatkan oleh Undang-undang Republik Indonesia Nomor 14 Tahun 2005 Tentang Guru dan Dosen, yaitu kompetensi pedagogik, kompotensi kepribadian, kompetensi profesional, dan kompetensi sosial.

Dalam buku Pengembangan Profesionalisme Guru dijelaskan tentang hakekat profesionalisme antara lain yang dikemukakan oleh Orstein dan Levine dalam Riva (2008) yang menegaskan bahwa pada dasarnya pekerjaan mengajar dapat dikategorikan kedalam tiga kategori yaitu mengajar merupakan: 1) Semiprofession, dilakukan melalui pelatihan dalam jangka pendek, bahkan mengajar dapat dilakukan oleh siapapun yang mengaku pernah diajar, karena itu mengajar cukup meniru saja tanpa latihan yang memadai. 2) Emerging profession, mengajar disatu sisi dikatakan suatu profesi, disisi lain dikatakan bukan suatu profesi bahkan bisa dikatakan kategori ambivalen. Mengajar merupakan suatu 
pekerjaan yang menuntut penyesuaian yang terus menerus, seiring dengan perubahan tuntutan masyarakat yang terus berkembang, sehingga seorang guru harus terus menerus melakukan up-dating ilmu dan materi, bahkan metodenya sehingga pembelajarannya benar-benar kontekstual. 3) Full Profession, mengajar merupakan suatu profesi yang anggotanya memiliki pengetahuan tertentu dan dapat menerapkan pengetahuanya untuk meningkatkan kesempatan dalam masalah pendidikan.

Dari pendapat para ahli di atas, maka dapat disimpulkan bahwa profesionalisme guru adalah kemampuan guru untuk melakukan tugas pokoknya sebagai pendidik dan pengajar meliputi kemampuan merencanakan, melakukan, dan melaksanakan evaluasi pembelajaran.

\section{Faktor yang Mempengaruhi Guru Profesional}

Meningkatkan mutu guru perlu adanya kebijakan meningkatkan mutu pendidikan guru, di antaranya meningkatkan jenjang pendidikan S1/S2/S3 dan program penyetaraan serta berbagai pelatihan dan penataran untuk meningkatkan kualitas kompetensi dan profesionalitas guru. Misalnya PKG (Pusat Kegiatan Guru, dan KKG (Kelompok Kerja Guru) dan Persatuan Guru Republik Indonesia (PGRI) atau lembaga pendidikan tinggi yang mendidik para calon guru dengan merancang kurikulum yang mampu membangun kompetensi dan profesionalitas para calon guru yang siap pakai. Profesionalisme menekankan kepada penguasaan ilmu pengetahuan atau kemampuan manajemen beserta strategi penerapannya.

Profesionalisme bukan sekadar pengetahuan teknologi dan manajemen tetapi lebih merupakan sikap, pengembangan profesionalisme lebih dari seorang teknisi bukan hanya memiliki keterampilan yang tinggi tetapi memiliki suatu tingkah laku yang dipersyaratkan. Guru yang professional tidak hanya dituntut untuk menguasai materi pembelajaran tetapi juga harus menguasai seluruh aspek yang ada dalam pembelajaran, karena pembelajaran yang bermakna adalah pembelajaran yang melibatkan peserta didik dan mencakup semua ranah pembelajaran, seperti aspek kognitif (berfikir), aspek affektif (prilaku) dan aspek psikomotor (keterampilan).

Profesionalisme guru dapat dilakukan; pertama; dengan memahami tuntutan standar profesi yang ada. Kedua; mencapai kualifikasi dan kompetensi yang dipersyaratkan. Ketiga; membangun hubungan kesejawatan yang baik dan luas termasuk lewat organisasi profesi. Keempat; mengembangkan etos kerja atau budaya kerja yang mengutamakan pelayanan bermutu tinggi kepada konstituen.Kelima; mengadopsi inovasi atau mengembangkan kreativitas dalam pemamfaatan teknologi komunikasi dan informasi mutakhir agar senantiasi tidak ketinggalan dalam kemampuannya mengelola pelajaran. (Muhson dalam Yusutria, 2017: 5).

Guru yang profesional bisa dipengaruhi oleh: (1) Jenjang pendidikan, (2) Pelatihan dan program penyetaraan serta berbagai penataran yang diikuti, (3) 
Membangun hubungan kesejawatan yang baik dan luas, (4) Mengembangkan etos kerja yang mengutamakan pelayanan bermutu tinggi kepada konstituen, (5) Mengadopsi inovasi dalam pemamfaatan teknologi komunikasi dan informasi mutakhir. (Yusutria, 2017: 5).

\section{Upaya Meningkatkan Kompetensi dan Profesionalisme Guru}

Upaya menjamin mutu guru agar tetap memenuhi standar kompetensi, diperlukan adanya suatu mekanisme yang memadai. Penjaminan mutu guru ini perlu dikembangkan berdasarkan pengkajian yang komprehensif untuk menghasilkan landasan konseptual dan empirik, melalui sistem sertifikasi. Menurut Nataamijaya (2004) dalam Mulyasa (2008), sertifikasi adalah prosedur yang digunakan oleh pihak ketiga untuk memberikan jaminan tertulis bahwa suatu produk, proses atau jasa telah memenuhi persyaratan yang ditetapkan.

Sertifikasi guru merupakan pemenuhan kebutuhan untuk meningkatkan kompetensi profesional. Oleh karena itu, proses sertifikasi dipandang sebagai bagian esensial dalam upaya memperoleh sertifikat kompetensi sesuai dengan standar yang telah ditetapkan. Sertifikasi guru merupakan proses uji kompetensi bagi calon atau guru yang ingin memperoleh pengakuan dan atau meningkatkan kompetensi sesuai profesi yang dipilihnya. Sertifikat ini sebagai bukti pengakuan atas kompetensi guru yang memenuhi standar untuk melakukan pekerjaan profesi guru pada jenis dan jenjang pendidikan tertentu. Sertifikasi guru merupakan upaya peningkatan mutu guru yang diikuti dengan peningkatan kesejahteraan guru, sehingga diharapkan dapat meningkatkan mutu pembelajaran dan mutu pendidikan di Indonesia secara berkelanjutan (Dediknas, 2008:1).

Menurut Sujanto (2009) sertifikasi guru mempunyai tujuan, antara lain 1) Menentukan kelayakan guru sebagai agen pembelajaran. Sebagai agen pembelajaran berarti guru menjadi pelaku dalam proses pembelajaran. Guru yang sudah menerima sertifikat pendidik dapat diartikan sudah layak menjadi agen pembelajaran. 2) Meningkatkan proses dan mutu pendidikan. Mutu pendidikan antara lain dapat dilihat dari mutu siswa sebagai hasil proses pembelajaran. 3) Meningkatkan martabat guru. 4) Meningkatkan profesionalisme. Guru yang profesional antara lain dapat ditentukan dari pendidikan, pelatihan, pengembangan diri, dan berbagai aktivitas lainnya terkait dengan profesinya.

Selain mempunyai tujuan, pelaksanaan, sertifikasi guru juga mempunyai manfaat. Manfaat utama dari sertifikasi guru ialah 1) Melindungi profesi guru dari dari praktik-praktik merugikan citra profesi guru. 2) Melindungi masyarakat dari praktek pendidikan yang tidak berkualitas dan professional. 3) Meningkatkan kesejateraan ekonomi guru. Untuk memperoleh sertifikat pendidik tidak semudah membalikkan telapan tangan, dan memerlukan kerja keras para guru. Sertifikat pendidik akan dapat diperoleh guru apabila mereka benar benar memiliki kompetensi dan profesionalisme. Bagi para guru yang memiliki kompetensi dan profesionalisme, hal ini mungkin bukan merupakan persoalan yang pelik, 
melainkan tinggal menunggu waktu. Sebaliknya, para guru yang kurang memiliki kompetensi dan profesionalisme, hal ini dapat menjadi persoalan yang pelik ketika giliran untuk disertifikasi telah tiba. Sehubungan dengan hal itu, sesuatu yang pasti adalah guru harus mempersiapkan diri sedini mungkin untuk disertifikasi, agar kesempatan yang baik itu tidak hilang begitu saja karena tidak adanya persiapan yang memadai. Guru harus siap mental, keilmuan, dan finansial. Dalam kaitan dengan persiapan dalam hal keilmuan, guru perlu meningkatkan kompetensi dan profesionalismenya dalam membangun paradigma insan generasi emas.

\section{SIMPULAN}

Kebijakan pemerintah tentang kualifikasi, kompetensi, dan sertifikasi guru yang implementasinya sedang dalam proses merupakan upaya untuk meningkatkan kualitas, kemampuan, dan kesejahteraan guru yang diharapkan dapat berdampak pada peningkatan mutu pendidikan di Indonesia guna membangun paradigma insan generasi emas. Guru dituntut untuk selalu dinamis mengikuti perkembangan ilmu pengetahuan, teknologi, dan informasi. Sebagai pendidik, sudah seharusnya guru harus belajar seumur hidup (long life education). Oleh karena itu, guru harus membangun dan mengembangkan dirinya, sehingga dia mampu menjadi pencetus "teori-teori" baru dalam konteks pembelajarannya untuk peningkatan mutu pendidikan.

Posisi guru sebagai salah satu profesi seharusnya diakui dalam kehidupan masyarakat. Guru sebagai profesi yang sejajar dengan profesi-profesi lainnya, seperti dokter, hakim, jaksa, akuntan, desainer interior, arsitektur, dan masih banyak yang lainnya. Untuk mengarah kepada kondisi tersebut, tentunya guru sendirilah yang harus mampu mengaktualisasikan kompetensinya, sehingga diakui oleh para pihak yang berkepentingan. Oleh karena itu, guru harus membangun dan mengembangkan dirinya, sehingga dia mampu mempertahankan kompetensi dan profesionalitas yang dimilikinya.

Adapun saran yang dapat diberikan peneliti yaitu perlu adanya upaya lain yang dapat dilakukan guna meningkatkan kualitas kompetensi profesionalisme guru. Dimana, tidak semua guru mendapatkan sertifikasi dalam pengembangan kompetensinya, maka perlu ada teknik atau pelatihan khusus dalam mengantisipasinya. Rekomendasi yang bisa diberikan terhadap profesionalisme guru dalam pengembangan kualitas kompetensi profesionalisme guru hendaknya dilaksanakan secara sungguh-sungguh. Selama pemerintah tidak sungguhsungguh mewujudkan profesionalisme guru dalam pengembangan kualitas pendidikan, bisa dipastikan bahwa mutu pendidikan akan menurun dalam membangun paradigm insan generasi emas 


\section{DAFTAR RUJUKAN}

Asmani, Jamal Ma'mur. 2009. 7 Kompetensi Guru Menyenangkan dan Profesional. Jogjakarta: Powerbook.

Depdiknas. 2008. Penilaian Kinerja Guru. Jakarta: Direktorat Tenaga Kependidikan Direktorat Jenderal Peningkatan Mutu Pendidik dan Tenaga Kependidikan.

Mulyasa, E. 2008. Standar Kompetensi dan Sertifikasi Guru. Bandung: Remaja Rosdakarya.

Riva Dede Mohamad. 2008. Upaya Meningkatkan Profesionalisme Guru. Tersedia: http://id.shvoong.com diakses tanggal 11April 2010.

Sanjaya Wina. 2006. Strategi Pembelajaran Berorientasi Standar Pendidikan. Jakarta: Kencana Prenada.

Sujanto, Bejo. 2009. Cara Efektif Menuju Sertifikasi Guru. Jakarta: Raih Asah Sukses.

Undang-undang Republik Indonesia Nomor 14 Tahun 2005 tentang Guru dan Dosen.

Yusutria. 2017. Profesionalisme guru dalam meningkatkan kualitas sumber daya manusia. Vol 2 No.1: 1-9 